\title{
ESTIMASI PRODUKSI PADI DENGAN ANALISIS CITRA SATELIT LANDSAT 8 DI KABUPATEN KLUNGKUNG PROVINSI BALI
}

\author{
Made Arya Bhaskara Putra ${ }^{\left.1^{*}\right)}$, I Wayan Nuarsa ${ }^{2)}$, I Wayan Sandi Adnyana ${ }^{2)}$ \\ ${ }^{1)}$ Program Studi Magister Pertanian Lahan Kering Universitas Udayana, Denpasar-Bali \\ ${ }^{2}$ Fakultas Pertanian Universitas Udayana, Kampus Bukit Jimbaran-Bali \\ *email: aryabhaskara02@yahoo.com.
}

\begin{abstract}
ESTIMATION OF RICE PRODUCTION USING LANDSAT 8 SATELLITE IN KLUNGKUNG REGENCY, BALI PROVINCE
\end{abstract}

Rice crop is one of the important commodities that must always be available, so estimation of rice production becomes very important to do before harvesting time to know the food availability. The technology that can be used is remote sensing technology using Landsat 8 Satellite. The aims of this study were (1) to obtain the model of estimation of rice production with Landsat 8 image analysis, and (2) to know the accuracy of the model that obtained by Landsat 8.The research area is located in three sub-districts in Klungkung regency. Analysis in this research was conducted by single band analysis and analysis of vegetation index of satellite image of Landsat 8. Estimation model of rice production was developed by finding the relationship between satellite image data and rice production data. The final stage is the accuracy test of the rice production estimation model, with $t$ test and regression analysis.The results showed: (1) estimation of rice production can be calculated between 67 to 77 days after planting; (2) there was a positive correlation between NDVI (Normalized Difference Vegetation Index) vegetation index value with rice yield; (3) the model of rice production estimation is $\mathrm{y}=2.0442 \mathrm{e}^{1.8787 \mathrm{x}}$ ( $\mathrm{x}$ is NDVI value of Landsat 8 and $\mathrm{y}$ is rice production); (4) The results of the model accuracy test showed that the obtained model is suitable to predict rice production with accuracy level is $89.29 \%$ and standard error of production estimation is \pm 0.443 ton/ha.Based on research results, it can be concluded that Landsat 8 Satellite image can be used to estimate rice production and the accuracy level is $89.29 \%$. The results are expected to be a reference in estimating rice production in Klungkung Regency.

Keywords: rice production, estimation model,landsat 8,vegetation index.

\section{PENDAHULUAN}

Tanaman padi merupakan salah satu komoditi penting yang harus selalu tersedia, mengingat padi menghasilkan beras yang menjadi makanan pokok masyarakat Indonesia. Tingginya kebutuhan beras tersebut, tentunya harus diimbangi dengan produksi padi, agar tidak menimbulkan kekurangan stok yang berakibat pada kerawanan pangan (Sari dan Sukojo, 2015). Data statistik produksi padi Kabupaten Klungkung menunjukkan bahwa, produksi padi di Kabupaten Klungkung pada tahun 2014 mencapai 32.062 ton, dengan luas panen 5.062 hektar. Jumlah produksi padi tersebut diupayakan dapat memenuhi kebutuhan pangan di Kabupaten Klungkung. Jumlah produksi padi tentunya sangat berkaitan dengan luas lahan pertanian yang digunakan untuk budidaya tanaman padi(Genc et al., 2014; Kania et $a l ., 2010)$. Oleh karena itu, distribusi penanaman, monitoring pertumbuhan, serta penyediaan data estimasi produksi padi di Kabupaten Klungkung sangat penting diketahui, untuk dapat mendukung manajemen produksi dan swasembada pangan khususnya beras di Kabupaten Klungkung. Kesalahan dalam memperkirakan produksi padi, dapat menyebabkan terganggunya ketersediaan beras, dan berdampak terhadap fluktuasi harga beras(Ali dan Salman, 2015; Said et al., 2015). Upaya yang dilakukan adalah dengan melakukan monitoring tanaman padi secara berkala, sehingga jumlah persediaan beras akan dapat diketahui.

Estimasi produksi padi hingga saat ini telah banyak dilakukan oleh beberapa instansi pemerintah, diantaranya; Badan Urusan Logistik (BULOG), Badan Pusat Statistik (BPS), Dirjen Bina Produksi Tanaman Pangan dan Hortikultura, serta Departemen Pertanian. Secara umum analisis estimasi produksi padi, masih dilakukan secara konvensional. Kelemahan dari metode konvensional, di antaranya adalah; waktu yang relatif lama, jumlah tenaga banyak, biaya tinggi, serta metode estimasi yang hanya dapat dilakukan pada masa panen saja (Said et al., 2015; Subrata dan Kusmana, 2003). Seiring dengan perkembangan teknologi, serta tuntutan penyediaan data yang cepat dan akurat menjadikan metode estimasi secara konvensional sulit untuk diterapkan(Ali dan Salman, 2015). Salah satu alternatif yang dapat digunakan adalah dengan teknologi penginderaan jauh.

Penginderaan jauh atau remote sensing merupakan ilmu yang digunakan untuk mendapatkan berbagai informasi tentang objek 
(permukaan bumi dan perairan) melalui analisis data yang dilakukan pada jarak tertentu tanpa harus melakukan kontak langsung dengan objek yang diteliti (Lillesand dan Kiefer, 2000). Berbagai teknologi penginderaan jauh telah digunakan untuk berbagai penelitian tentang tanaman padi, mulai dari penggunaan citra digital, foto udara, hingga menggunakan citra satelit. Estimasi produksi padi dengan menggunakan citra satelit dapat mencakup lahan tertentu, serta mampu memonitor kondisi fisik tanaman padi secara berkala(Ali dan Salman, 2015; Said et al., 2015). Pengembangan model estimasi produksi padi dilakukan untuk dapat menduga hasil panen padi sebelum masa panen dengan memanfaatkan data citra satelit Landsat 8. Satelit Landsat 8 merupakan satelit terbaru yang diluncurkan pada tahun 2013, satelit ini memiliki berbagai keunggulan dibandingkan dengan versi sebelumnya. Keunggulan yang paling menonjol dari satelit Landsat 8 adalah jumlah band yang lebih banyak, yaitu 11 band, serta rentang nilai digital number (DN) yang lebih panjang, antara 0-4096 (Purwanto, 2015; Sitanggang, 2010).

Analisis data citra satelit Landsat yang dilakukan secara temporal, terhadap ciri-ciri dan perubahan kenampakan citra, akan dapat digunakan untuk membangun model estimasi produksi padi, serta memantau umur tanaman padi(Nuarsa dan Nishio, 2007). Salah satu informasi yang dapat diambil dari citra satelit adalah tingkat kehijauan tanaman (greenness) yang memiliki hubungan dengan hasil produksi padi serta perubahan pertumbuhan tanaman padi(Sudarsono et al., 2016). Melihat peluang tersebut, maka perlu dilakukan penelitian lebih lanjut tentang model estimasi produksi padi menggunakan citra Landsat 8, sehingga diperoleh model estimasi terbaik yang dapat menduga produksi padi secara tepat dan akurat.

Tujuan dari penelitian ini adalah: (1) untuk mendapatkan model estimasi umur dan produksi padi dengan analisis citra satelit Landsat 8 di Kabupaten Klungkung, serta (2) untuk mengetahui akurasi model estimasi produksi padi dengan analisis citra satelit Landsat 8.

\section{METODE PENELITIAN}

\subsection{Tempat dan Waktu Penelitian}

Penelitian ini dilakukan di Kabupaten Klungkung, Provinsi Bali dengan koordinat $115^{\circ}$ 21'28" - 115 37’ 43" BT dan 8 27’ 37" - 8 49'00" LS, dan merupakan Kabupaten Klungkung bagian daratan, meliputi Kecamatan Banjarangkan, Kecamatan Klungkung, dan Kecamatan Dawan (Gambar 1). Penelitian dilakukan dari bulan Juni 2017 sampai dengan bulan Desember 2017.

\subsection{Alat dan Bahan}

Alat yang digunakan dalam penelitian ini meliputi peralatan pengolahan data dan peralatan lapangan.Peralatan pengolahan data meliputi seperangkat komputer lengkap dengan software ArcGis 10.2.2, sedangkan peralatan lapangan meliputi GPS, Peta Kerja, Meteran, Klorofil Meter, Alat Tulis, serta Kamera. Bahan yang digunakan dalam penelitian ini berupa citraLandsat 8 yang diunduh melalui website: //https:earthexplorer. usgs.gov//.

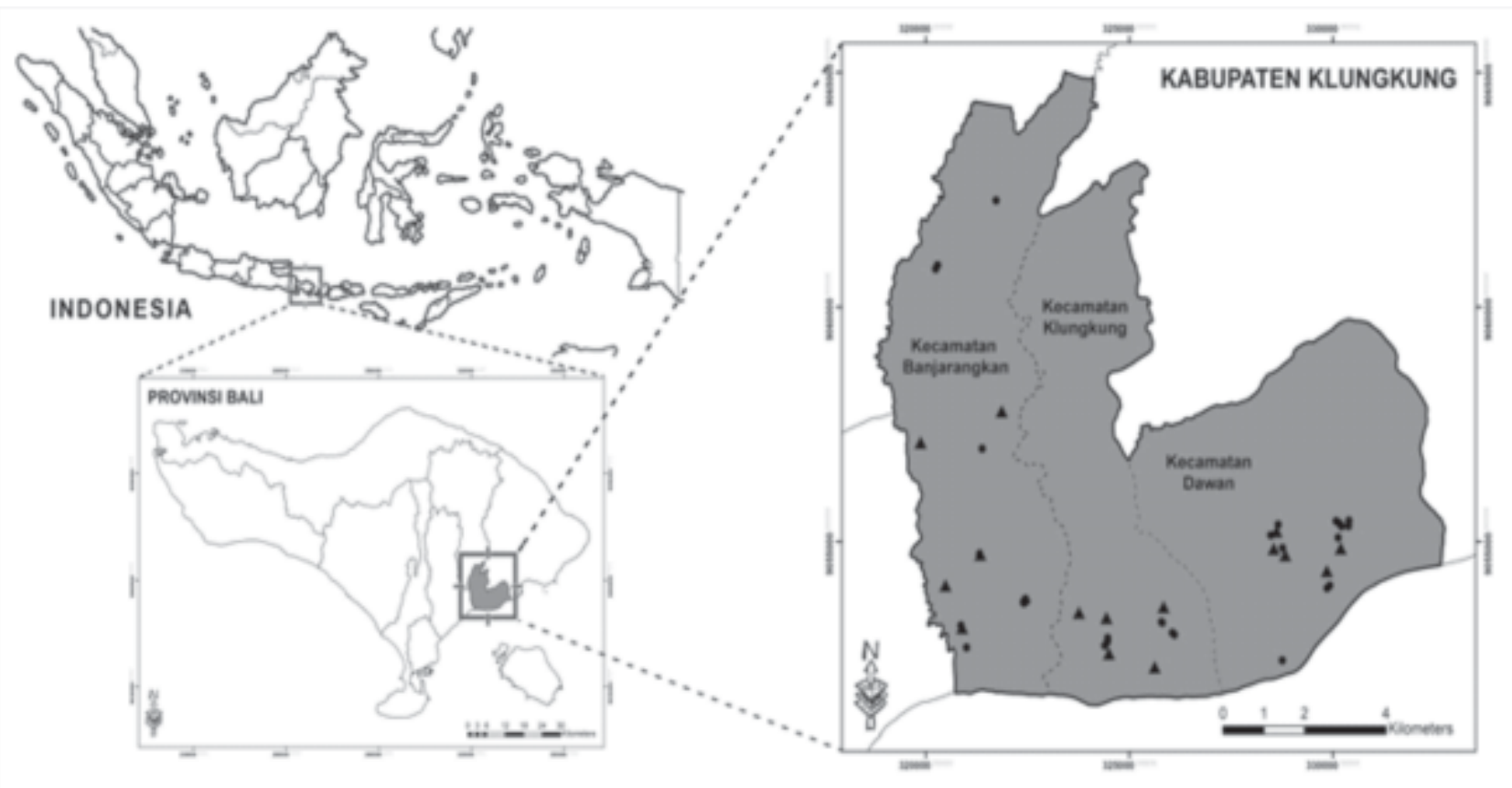

Gambar 1.

Lokasi Penelitian: Kabupaten Klungkung, Provinsi Bali, Indonesia. Lokasi pengamatan sampel (tanda segitiga) dengan jumlah 15 lokasi, serta lokasi uji ketelitian model (tanda lingkaran) dengan jumlah 31 lokasi. 


\subsection{Observasi Lapang}

Pengamatan lapangdilakukan pada 15 lokasi pengambilan sampel di tiga kecamatan di Kabupaten Klungkung. Adapun data-data yang diamati dalam pengamatan lapang, diantaranya adalah; 1) data pertumbuhan tanaman, meliputi : tinggi tanaman, jumlah anakan per rumpun, serta nilai klorofil daun tanaman padi; 2) data tutupan lahan oleh tanaman padi; 3) data teknik budidaya tanaman padi; 4) data kondisi lokasi pengamatan; 5) data koordinat lokasi; 6) data tanggal tanam dan panen padi; serta 7) data hasil produksi padi. Observasi dilakukan secara real time, yang mana pengamatan dilakukan pada saat satelit Landsat 8 melewati daerah penelitian. Selain secara real time, pengamatan juga dilakukan secara berkala setiap minggunya.

\subsection{Analisis Data}

Setelah data terkumpul kemudian dilakukan proses pengolahan dan analisis data, yang dibagi menjadi beberapa tahapan, diantaranya;

1. Pengolahan citra Landsat 8

Citra satelit yang telah terkumpul selanjutnya diolah dengan menggunakan software ArcGis 10.2.2. Tahap pertama dilakukan koreksi radiometrik untuk mengurangi efek atmosfer yang dapat menyebabkan nilai reflektansi yang dipantulkan objek mengalami gangguan. Koreksi radiometrik dilakukan dengan menggunakan nilai TOA (Top of Atmosfer), yang mana nilai tersebut merupakan hasil konversi dari nilai Digital Number (DN) dengan menggunakan beberapa persamaan 1 dan 2 .

$$
\rho \lambda^{\prime}=M_{\rho} Q_{\text {cal }}+A_{\rho}
$$

Keterangan:

ñë = Reflektan TOAplanetary, tanpa dikoreksi sudut matahari

$M_{\tilde{\mathrm{n}}}=$ Perkiraan saluran spesifik dengan faktor rescaling dari metadata (REFLECTANCE-_MULTI_BAND_x, dimana $\mathrm{x}$ adalah nomor saluran)

$\mathrm{A}_{\tilde{\mathrm{n}}}=$ Penambahan saluran spesifik dengan faktor rescaling dari metadata (REFLECTANCE-_ADD_BAND_x, dimana x adalah nomor saluran)

$\mathrm{Q}_{c a l}=$ Kuantitas dan kalibrasi produk standar nilai piksel (DN)

TOA reflectance dengan koreksi sudut matahari dilakukan dengan menggunakan persamaan berikut:

$$
\rho \lambda=\frac{\rho \lambda}{\cos \left(\theta_{S Z}\right)}=\frac{\rho \lambda}{\sin \left(\theta_{S E}\right)}
$$

Keterangan:

$\tilde{\text { n̈ë }}=$ Reflektan TOAplanetary

$\mathrm{u}_{\mathrm{SE}}=$ Sudut elevasi matahari lokal. Sudut elevasi matahari pada pusat citra dalam derajat, nilai ini terdapat pada metadata $\left(S U N_{-}\right.$ ELEVATION)

$\mathrm{u}_{\mathrm{SZ}}=$ Sudut solar zenith lokal; $\mathrm{u}_{\mathrm{SZ}}=90^{\circ}-\mathrm{u}_{\mathrm{SE}}$

Melalui koreksi radiometrik, maka diperoleh nilai reflektan citra satelit Landsat 8 yang telah terbebas dari noise ataupun gangguan atmosfir, yang selanjutnya digunakan dalam analisis statistik.

Cropping Area dilakukan untuk membatasi daerah penelitian sehingga dapat mengurangi kapasitas memori dan memudahkan dalam proses analisis citra. Cropping Area dilakukan dengan menggunakan fitur Extract by Mask pada software ArcGis.

\section{Analisis Citra Landsat 8}

Analisis citra Landsat 8 yang dilakukan meliputi analisis indeks vegetasi dan analisis saluran (band) tunggal citra Landsat 8. Analisis indeks vegetasi yang dilakukan dalam penelitian ini, diantaranya; Normalized Difference Vegetation Index (NDVI), Transform Vegetation Index (TVI), Ration Vegetation Index (RVI), Difference Vegetation Index (DVI), Soil Adjusted Vegetation Index (SAVI), serta Rice Growth Vegetation Index (RGVI). Persamaan dari masing-masing indeks vegetasi tersebut seperti ditampilkan pada persamaan 3 sampai 8 .

$$
\begin{aligned}
& \text { a. } \quad \text { NDVI }=\frac{\text { NIR }-R \theta d}{\text { NIR }+ \text { Red }} \\
& \text { b. } \quad T V I=\frac{100}{\sqrt{\frac{\text { NIR-Red }}{\text { NIR+Red }}+0.5}} \\
& \text { c. } \quad R V I=\frac{\text { NIR }}{\text { Red }} \\
& \text { d. } \quad D V I=N I R-R e d \\
& \text { e. } \quad S A V I=\frac{\text { NIR-Red }}{\text { NIR }+ \text { Red }+L}(1+L) \\
& \text { f. } \quad R G V I=1-\frac{(\text { Blue }+ \text { Red })}{(\text { NIR }+ \text { SWIR } 1+\text { SWIR 2) }}
\end{aligned}
$$

Dimana NIR, Blue, Red, L, SWIR 1, dan SWIR 2 masing-masing merupakan saluran infra merah dekat (band 5), saluran biru (band 2), saluran merah (band 4), faktor koreksi background brightness $(\mathrm{L}=$ 0,5), Short-Wave Infrared 1 (band 6), serta ShortWave Infrared 2 (band 7). Selain analisis indeks vegetasi, dalam penelitian ini juga dilakukan analisis saluran citra Landsat 8 secara tunggal. Adapun beberapa saluranyang digunakan adalah saluran (band) 2, 3, 4, 5, 6, dan 7. Nilai indeks vegetasi dan nilai spektral citra Landsat 8 yang diperoleh kemudian dianalisis secara statistik untuk dihubungkan dengan kondisi tanaman padi di lapangan. Pengamatan citra Landsat 8 yang dilakukan secara multiwaktu, akan menghasilkan trend peningkatan atau penurunan nilai indeks 
vegetasi dan nilai spektral dari masing-masing citra Landsat 8.

3. Hubungan korelasi antara data citra Landsat 8 dengan data pengamatan lapang

Model estimasi produksi padi diperoleh dari adanya hubungan korelasi yang erat antara data citra Landsat 8 dengan data lapangan. Oleh karena itu, langkah selanjutnya adalah menentukan hubungan korelasi antara dua variabel tersebut. Adapun persamaan yang digunakan, seperti pada persamaan 9 sampai 10 .

i. Persamaan linier: $y= \pm a+b x$

ii. Persamaan kuadratik $: y=a x^{2}+b x+c$

iii. Persamaan eksponensial $: y=e^{a x+b}$

Persamaan yang diperoleh, selanjutnya dianalisis dengan persamaan 12 dan 13, untuk mendapatkan nilai koefisien determinasi $\left(\mathrm{R}^{2}\right)$ serta standar error (SE).

$R^{2}=\frac{n\left(a \sum Y+b_{1}-\sum Y X_{1}-\left(\sum Y\right)^{2}\right.}{n\left(\sum Y^{2}-\left(\sum Y\right)^{2}\right.}$

$S E=\sqrt{\frac{\sum\left(y-y^{\prime}\right)^{2}}{n}}$

Nilai koefisien determinasi $\left(\mathrm{R}^{2}\right)$ yang tinggi dan nilai standar error (SE) yang rendah menunjukkan bahwa model yang dihasilkan dari penelitian merupakan model terbaik yang dapat digunakan untuk mengetahui umur tanaman padi di lapanganserta melakukan estimasi produksi tanaman padi.

\section{Uji Ketelitian Model}

Pengujian ketelitan model dilakukan dengan cara membandingkan antara hasil estimasi citra Landsat 8 dengan hasil produksi padi yang diperoleh di lapangan. Data yang digunakan untuk melakukan uji ketelitian model berbeda dengan data yang digunakan untuk membangun model estimasi. Data yang digunakan untuk uji ketelitian merupakan data statistik produksi padi yang telah dilengkapi dengan data koordinat lokasi panen padi, tanggal penanaman padi, serta tanggal panen padi. Uji ketelitian model dilakukan dengan cara melakukan uji t, untuk mengetahui tingkat kecocokan model serta melakukan analisis regresi untuk mendapatkan persentase ketelitian dan standar error model estimasi produksi padi. Apabila persentase ketelitian model lebih dari 80\%, maka model tersebut sangat baik digunakan untuk melakukan estimasi produksi padi di Kabupaten Klungkung.

\section{HASIL DAN PEMBAHASAN}

\subsection{Pola Pertumbuhan Tanaman Padi}

Hasil pengamatan lapang, menunjukkan bahwa pertumbuhan tanaman padi sangat terlihat mulai dari awal penanaman hingga tanaman padi dipanen.Variabel yang menjadi fokus pengamatan, diantaranya; tinggi tanaman, jumlah rumpun, klorofil daun, serta persentase tutupan lahan oleh tanaman padi seperti ditampilkan pada Gambar 2.

Tanaman padi secara umum memiliki pola pertumbuhan yang membentuk kurve parabolik, kurve yang terbentuk bergantung pada variabel pertumbuhan yang diamati (Murtiningrum et al., 2011). Pertumbuhan tinggi tanaman padi terus meningkat sejak awal penanaman hingga akhirnya tanaman dipanen. Jumah rumpun tanaman padi, berdasarkan hasil pengamatan menunjukkan peningkatan pada awal penanaman padi, hingga mencapai puncak pada umur tertentu dan akhirnya kembali menurun hingga tanaman dipanen. Tutupan lahan sawah oleh tanaman padi terus meningkat dari awal masa penanaman hingga mencapai puncaknya (100\% tertutupi) menjelang masa panen. Perkembangan klorofil daun secara umum meningkat pada awal pertumbuhan hingga mencapai puncaknya pada umur tertentu dan akhirnya menurun saat proses pematangan gabah sampai memasuki masa panen.

\subsection{Hubungan data citra Landsat 8 terhadap umur tanaman padi}

Citra satelit Landsat 8 yang digunakan dalam penelitian ini adalah sebanyak lima buah, dengan tanggal perekaman citra adalah; tanggal 26 Agustus 2017, 11 September 2017, 27 September 2017, 13 Oktober 2017, dan 29 Oktober 2017. Seluruh citra yang diperoleh dianalisis untuk mendapatkan nilai spektral dan nilai indeks vegetasi citra Landsat 8, yang kemudian dikorelasikan dengan umur tanaman padi di lapangan. Hubungan korelasi antara nilai spektral (band 2, 3, 4, 5, 6, dan 7) dengan umur tanaman padi, menunjukkan bahwa analisis citra Landsat 8 dengan menggunakan analisis band tunggal belum mampu menggambarkan umur tanaman padi di lapangan. Hal tersebut ditunjukkan oleh kecilnya nilai koefisien korelasi $\left(\mathrm{R}^{2}\right)$ untuk setiap $b$-and yang dianalisis. Hubungan korelasi terbaik ditunjukkan oleh band 4 dengan nilai $\mathrm{R}^{2} 0.5015$, diikuti oleh band 7, 3, 6, 2, dan 5 dengan nilai $\mathrm{R}^{2}$ berturut-turut adalah 0.4648, 0.4639, 0.457, 0.4432, dan 0.4242 (Gambar 3). 


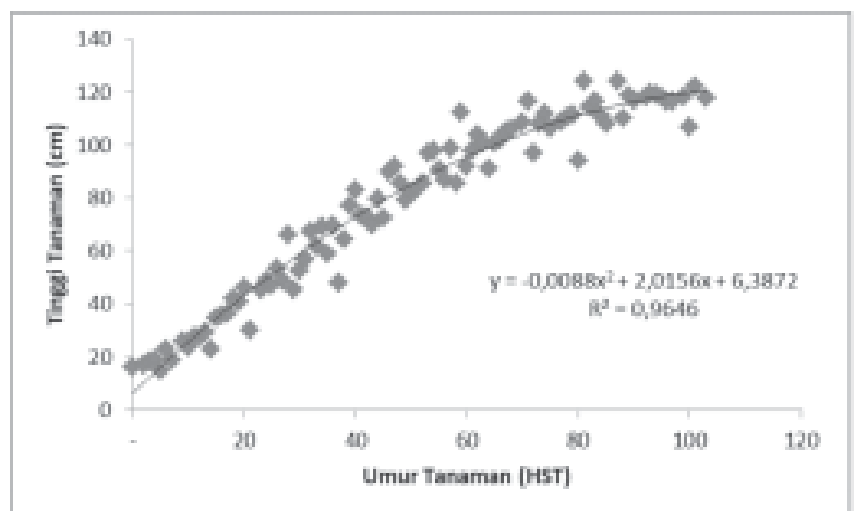

(a)

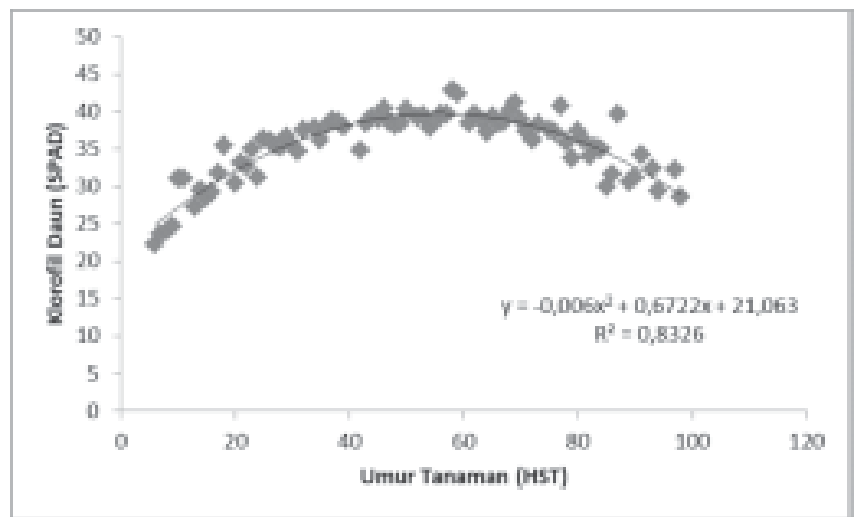

(c)

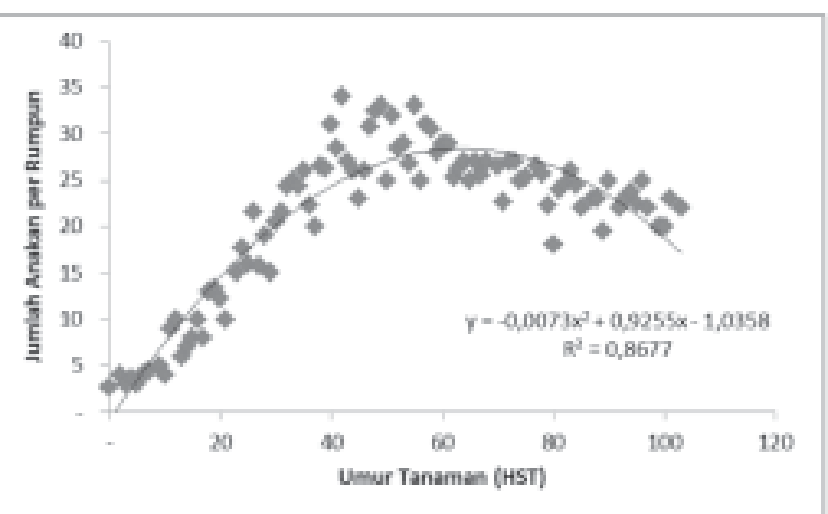

(b)

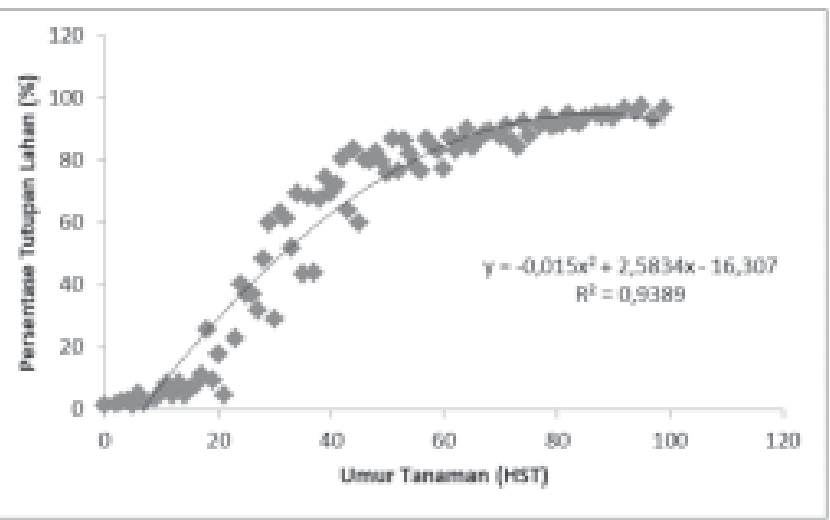

(d)

Gambar 2.

Grafik pola pertumbuhan tanaman padi di lapangan, dengan variabel; tinggi tanaman, jumlah rumpun, klorofil daun, serta persentase tutupan lahan sawah.

Analisis indeks vegetasi yang dilakukan dalam penelitian ini, diantaranya; NDVI, TVI, RGVI, RVI, DVI, dan SAVI. Nilai dari masing-masing indeks vegetasi tersebut selanjutnya dikorelasikan dengan umur tanaman padi di lapangan. Hasil analisis korelasi membentuk hubungan kuadratik yang berbeda-beda untuk setiap indeks vegetasi yang digunakan (Gambar 4). Terdapat tiga indeks vegetasi yang menunjukkan hubungan korelasi terbaik, diantaranya; TVI, NDVI, dan RGVI dengan nilai $\mathrm{R}^{2}$ berturut-turut adalah 0.9316, 0.9189, dan 0.893. Tiga indeks vegetasi lainnya seperti RVI, DVI, dan SAVI menunjukkan korelasi yang kurang baik, dengan nilai $\mathrm{R}^{2}$ berturut-turut adalah $0.7797,0.4069$, dan 0.6531. Penggunaan beberapa band sebagai indeks vegetasi dapat menggambarkan umur padi yang lebih baik dibandingkan dengan hanya menggunakan band tunggal (Sari dan Sukojo, 2015; Sudarsono et al., 2016).

Hasil penelitian yang diperoleh sejalan dengan penelitian Wahyunto et al. (2006), yang menyatakan bahwa nilai indeks vegetasi bernilai rendah pada awal waktu tanam padi. Seiring dengan bertambahnya umur tanaman padi, indeks vegetasi juga meningkat hingga mencapai puncak pertumbuhan tanaman padi pada umur sekitar dua bulan dan kemudian menurun kembali sampai akhirnya tanaman padi dipanen(Panuju et al., 2009). Pertumbuhan tanaman padi yang membentuk kurva parabolik, menunjukkan bahwa pada umur tertentu nilai indeks vegetasi (selain pada nilai optimum) akan mempunyai makna yang ganda(Nuarsa et al., 2011).

\subsection{Persamaan Perkembangan Umur Tanaman Padi}

Berdasarkan hasil analisis korelasi data citra Landsat 8 dengan data pengamatan di lapangan, maka terpilihlah tiga korelasi terbaik yang kemudian dianalisis lebih lanjut. Tiga korelasi terbaik tersebut diantaranya NDVI, TVI dan RGVI, dengan persamaan:

1. NDVI (Normalized Difference Vegetation Index) : $\mathrm{y}=-0.0001 \mathrm{x}^{2}+0.0143 \mathrm{x}+0.2913$

2. TVI (Transformed Vegetation Index) : $\mathrm{y}=0.0052 \mathrm{x}^{2}-0.6519 \mathrm{x}+110.03$

3. RGVI (Rice Growth Vegetation Index) : $y=-1 E-04 x^{2}+0.0123 x+0.3389$

Melalui persamaan korelasi yang diperoleh, maka umur tanaman padi pada saat nilai indeks vegetasi berada pada titik maksimum akan dapat 


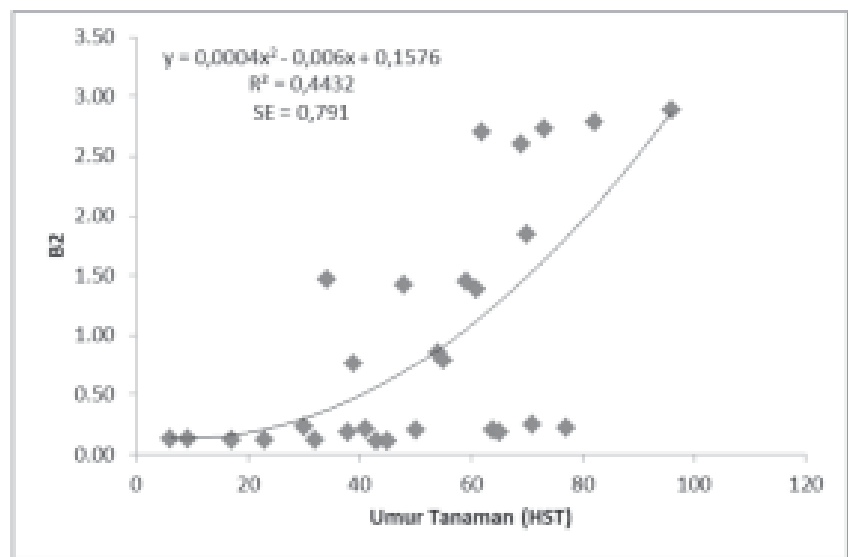

(a)

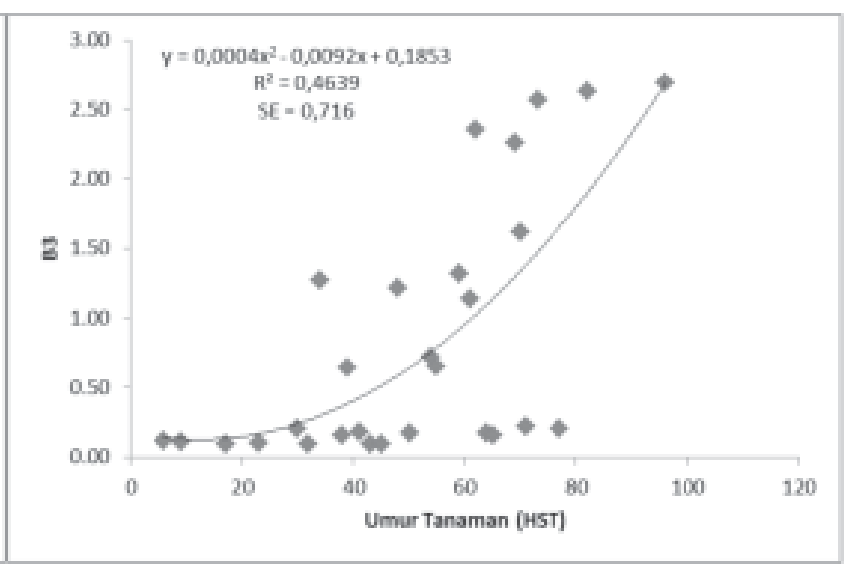

(b)

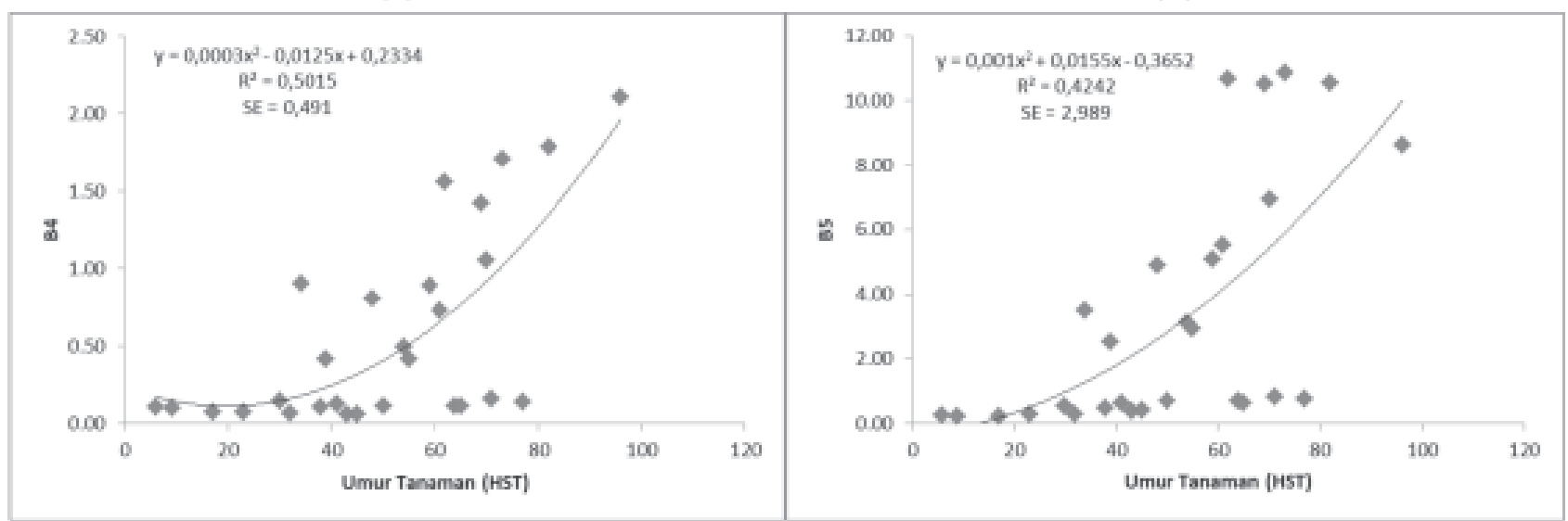

(c)

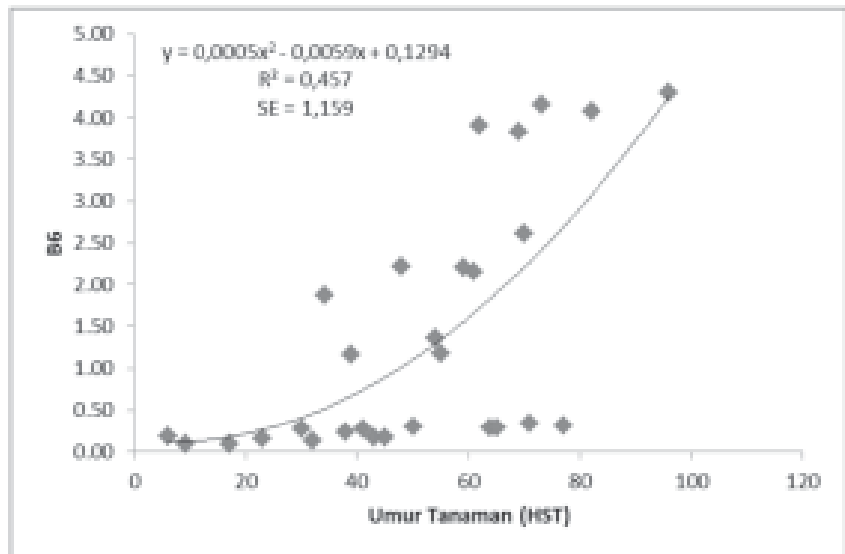

(d)

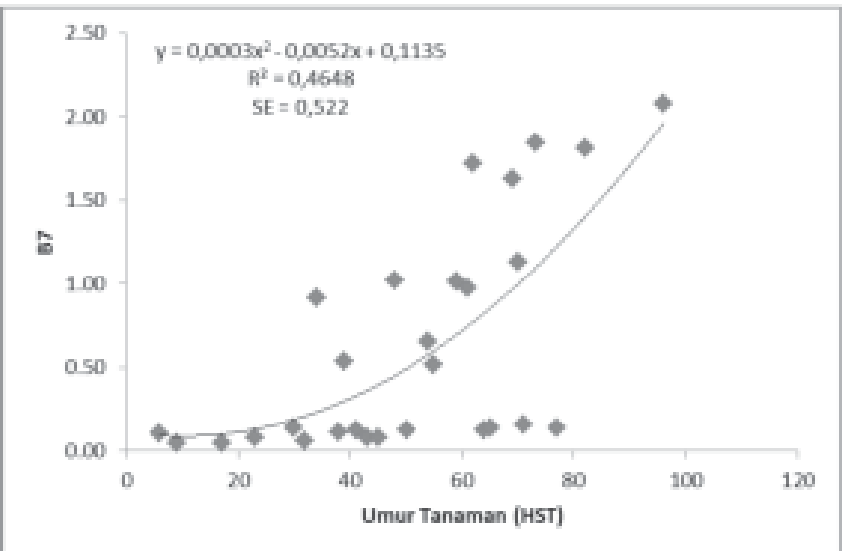

(e)

Gambar 3.

Grafik hubungan antara umur tanaman padi terhadap nilai spektral analisisband tunggal citra Landsat 8, meliputi; band2, band3, band4, band5, band6, danband7.

ditentukan menggunakan persamaan 17.

$x=\frac{-b}{2 a}$

Persamaan tersebut merupakan turunan dari persamaan umum yaitu; $\mathrm{y}=\mathrm{ax}^{2}+\mathrm{bx}+\mathrm{c}$ (dimana $\mathrm{y}$ adalah indeks vegetasi dan $\mathrm{x}$ adalah umur tanaman padi). Hasil analisis menunjukkan bahwa umur puncak tanaman padi pada masing-masing nilai indeks vegetasi adalah; NDVI pada umur 72 hari, TVI pada umur 63 hari, dan RGVI pada umur 62 hari. Umur tanaman tersebut merupakan fase transisi antara fase vegetatif dan fase reproduktif tanaman padi (Nuarsa et al., 2012). Penentuan umur tanaman ini sangat penting, mengingat penentuan umur tersebut akan menjadi acuan dalam menduga produksi padi di lapangan. 


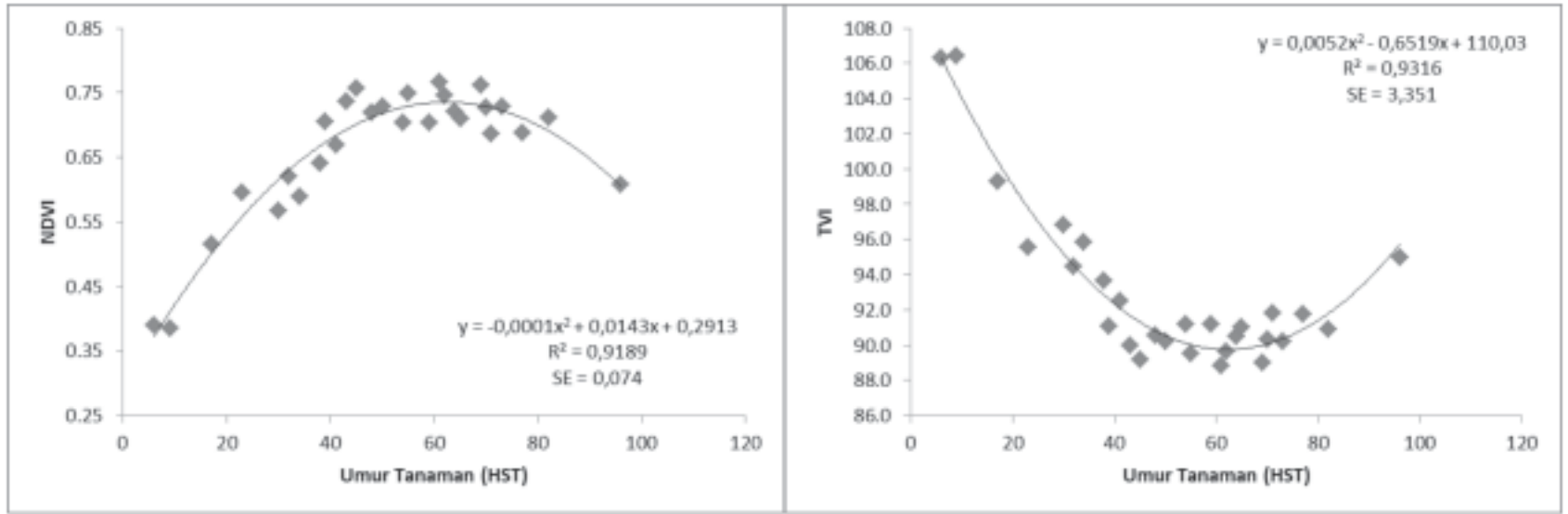

(a)

(b)
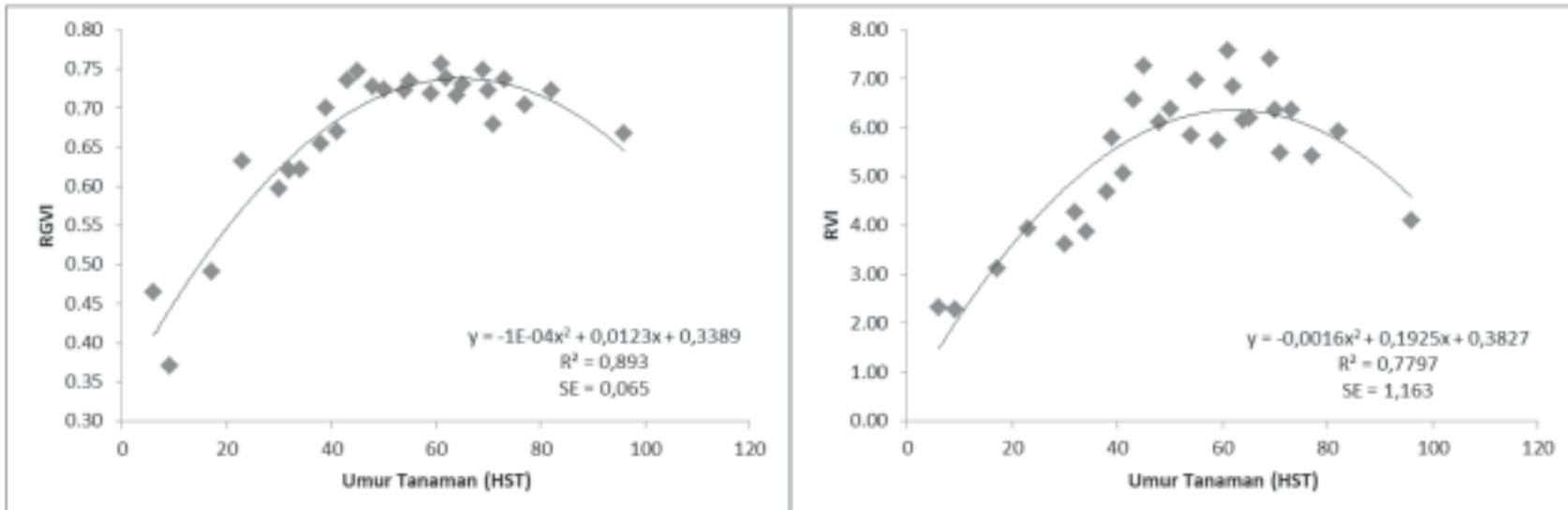

(c)

(d)

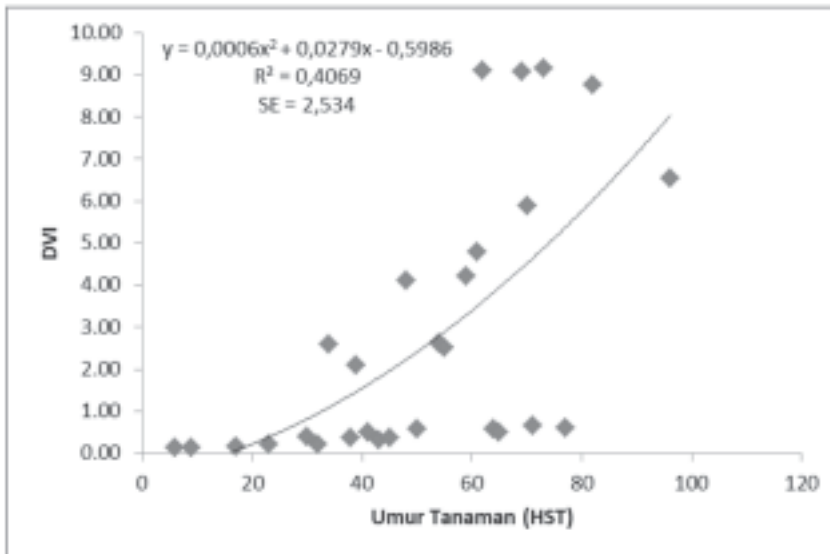

(e)

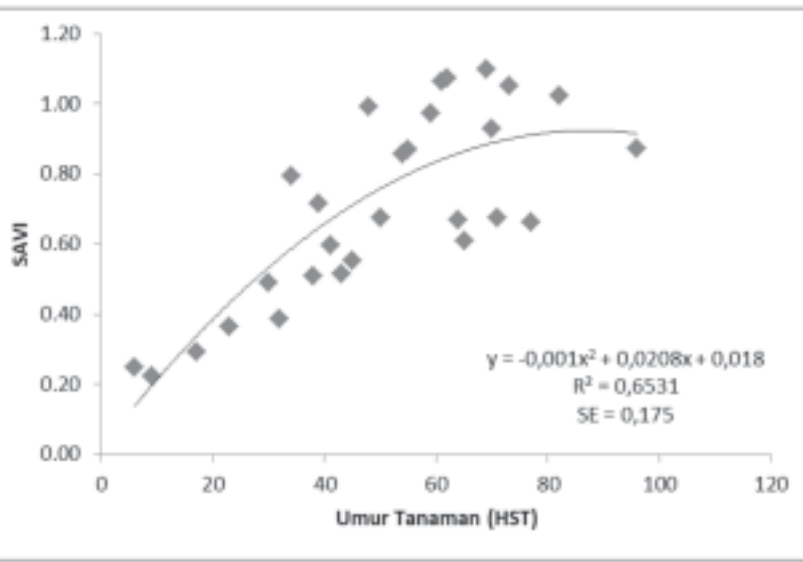

(f)

Gambar 4.

Grafik hubungan antara umur tanaman padi terhadap indeks vegetasi citra satelit, meliputi; NDVI (Normalized Difference Vegetation Index), RVI (Ratio Vegetation Index), DVI (Difference Vegetation Index), TVI (Transformed Vegetation Index), SAVI (Soil-Adjusted Vegetation Index), RGVI (Rice Growth Vegetation Index).

\subsection{Persamaan pendugaan produksi padi}

Pengembangan model estimasi produksi padi dilakukan pada rentang umur \pm 5 hari dari umur puncak masing-masing indeks vegetasi. Adapun umur yang ditetapkan untuk masing-masing indeks vegetasi adalah; (a) NDVI = umur 67 hari sampai 77 hari; (b) TVI = umur 58 hari sampai 68 hari; dan (c) RGVI = umur 57 hari sampai 67 hari. Hasil analisis korelasi antara indeks vegetasi citra Landsat 8 dengan hasil produksi padi, menunjukkan bahwa algoritma NDVI memberikan korelasi terbaik dengan nilai $R^{2} 0.9298$ dibandingkan dengan TVI maupun RGVI dengan nilai $\mathrm{R}^{2} 0.7278$ dan 0.6098 (Gambar 6).

Adapun persamaan pendugaan terbaik yang terpilih untuk dapat menduga hasil produksi padi adalah $\mathrm{y}=2.0442 \mathrm{e}^{1.8787 \mathrm{x}}$ (dimana $\mathrm{x}$ adalah nilai NDVI citra Landsat 8 dan y merupakan hasil produksi padi). Persamaan pendugaan yang diperoleh 


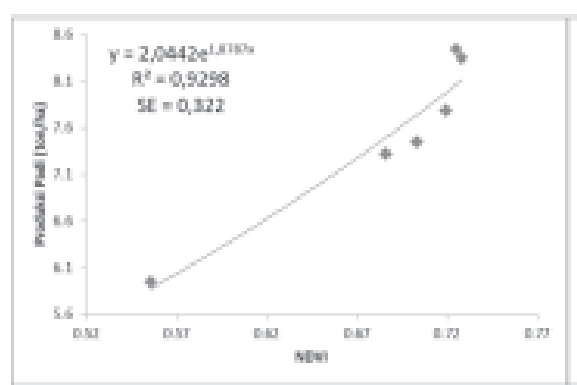

(a)

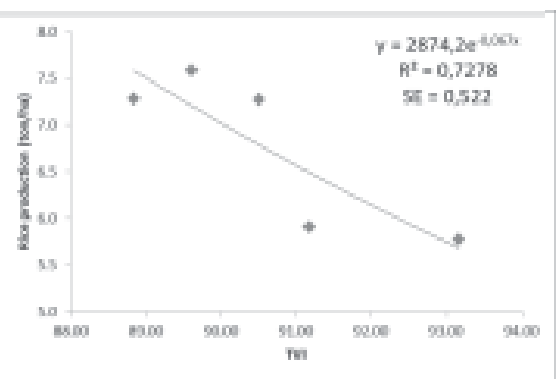

(b)

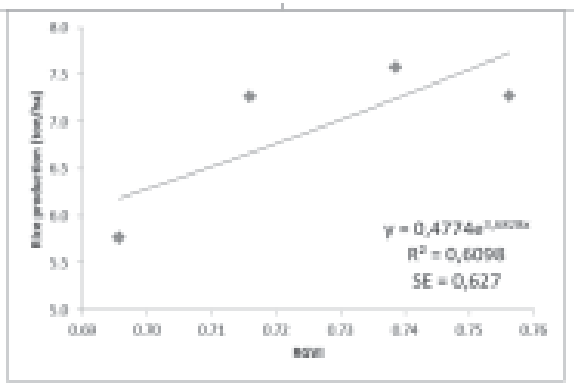

(c)

Gambar 6.

Hubungan korelasi antara produksi padi dengan nilai indeks vegetasi NDVI (umur 67 - 77 hari); TVI (umur 58 - 68 hari); RGVI (umur 57 - 67 hari)

menunjukkan bahwan nilai NDVI citra Landsat 8 pada kodisi normal akan berkorelasi positif terhadap hasil produksi tanaman padi. Akibat dari korelasi positif tersebut adalah, apabila terjadi kenaikan nilai NDVI citra Landsat 8 maka hasil produksi padi juga akan ikut meningkat, dan begitupula sebaliknya. Nilai NDVI dapat menjadi alat yang efektif dalam menduga hasil produksi padi (Siyal et al., 2015).

3.5. Uji Ketelitian Hasil Estimasi Produksi Padi dengan Citra Landsat 8

Uji ketelitian dilakukan untuk menentukan akurasi dari model estimasi produksi padi yang diperoleh. Hasil estimasi yang diperoleh dari model estimasi poduksi selanjutnya dibandingkan dengan data statistik produksi padi Kabupaten Klungkung. Uji ketelitian dalam penelitian ini dilakukan dengan dua cara. Pengujian pertama dilakukan untuk mengetahui kecocokan model dengan menggunakan uji t, serta pengujian kedua dilakukan dengan analisis regresi untuk mengetahui persentase ketelitian model.

Hasil estimasi produksi padi dengan citra Landsat 8 dapat memberikan hasil yang lebih besar ataupun lebih kecil dibandingkan dengan data statistik produksi padi (Tabel 1). Berdasarkan analisis citra satelit Landsat 8 yang dilakukan, diketahui bahwa rata-rata hasil produksi padi di Kabupaten Klungkung adalah 7.24 ton/ha, sedangkan berdasarkan data statistik diperoleh rata-rata produksi 7.20 ton/ha. Hasil yang diperoleh menunjukkan perbedaan yang sangaat kecil (hanya 0,04 ton/ha), sehingga ketika diuji dengan uji t diperoleh bahwa antara hasil statistik dengan hasil estimasi tidak berbeda nyata (non signifikan) pada tarafá $=0.73$. Berdasarkan hal tersebut maka dapat dikatakan bahwa analisis citra satelit Landsat 8 cocok untuk diaplikasikan untuk menduga produksi padi.

Tabel 1. Uji ketelitian model dengan cara membandingkan antara hasil statistik dengan hasil estimasi citra Landsat8

\begin{tabular}{|c|c|c|c|c|c|c|}
\hline No & Nama Lokasi & Umur Tanaman (HST) & $\begin{array}{l}\text { Hasil Statistik (ton/ha) } \\
\text { (a) }\end{array}$ & $\begin{array}{l}\text { Hasil Estimasi (ton/ha) } \\
\text { (b) }\end{array}$ & $\begin{array}{l}\text { Selisih } \\
(c)=(a)-(b)\end{array}$ & $\begin{array}{l}\text { Kuadrat } \\
(d)=(c)^{2}\end{array}$ \\
\hline 1 & Timuhun & 70 & 7.38 & 7.83 & -0.45 & 0.20 \\
\hline 2 & Takmung & 67 & 5.32 & 4.94 & 0.38 & 0.14 \\
\hline 3 & Negari & 74 & 7.10 & 7.53 & -0.43 & 0.19 \\
\hline 4 & Gelgel & 75 & 8.54 & 8.33 & 0.21 & 0.05 \\
\hline 5 & Gelgel & 72 & 8.68 & 8.24 & 0.44 & 0.19 \\
\hline 6 & Gelgel & 69 & 7.69 & 8.13 & -0.44 & 0.19 \\
\hline 7 & Nyalian & 77 & 5.66 & 5.35 & 0.31 & 0.10 \\
\hline 8 & Nyalian & 77 & 5.70 & 5.34 & 0.36 & 0.13 \\
\hline 9 & Tusan & 77 & 5.76 & 5.66 & 0.10 & 0.01 \\
\hline 10 & Getakan & 77 & 8.06 & 8.23 & -0.17 & 0.03 \\
\hline 11 & Dawan Klod & 76 & 8.38 & 8.13 & 0.25 & 0.06 \\
\hline 12 & Dawan Klod & 77 & 7.68 & 7.39 & 0.29 & 0.08 \\
\hline 13 & Gelgel & 67 & 7.10 & 7.99 & -0.89 & 0.79 \\
\hline \multirow[t]{6}{*}{14} & Pikat & 71 & 7.79 & 8.31 & -0.52 & 0.27 \\
\hline & Jumlah & & 100.84 & 101.40 & -0.56 & 2.44 \\
\hline & Rata-rata & & 7.20 & 7.24 & -0.04 & 0.17 \\
\hline & t - Hitung & & -0.35 & & & \\
\hline & $\mathrm{t}-$ Tabel $5 \%$ & & 2.16 & & & \\
\hline & $\alpha$ & & 0.73 & & & \\
\hline
\end{tabular}




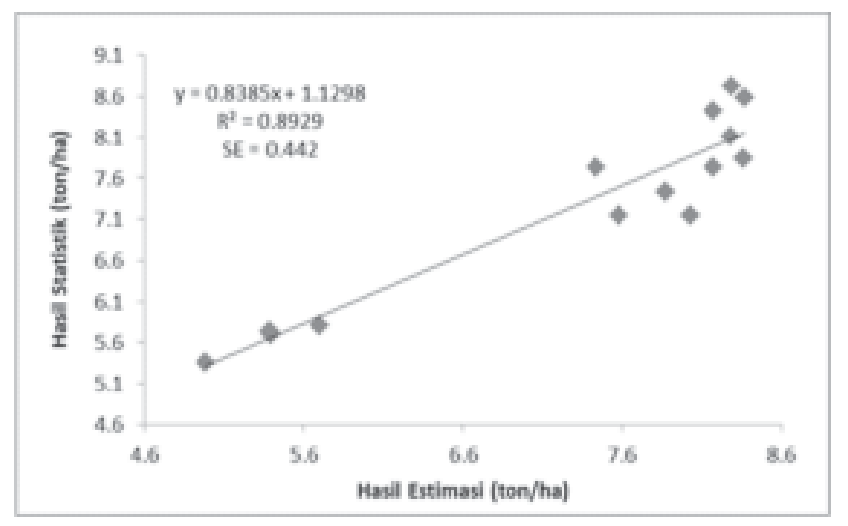

Gambar 7

Grafik uji ketelitian model estimasi produksi padi dengan citra satelit Landsat 8

Hasil analisis regresi menunjukkan bahwa terdapat hubungan yang linier antara hasil statistik dan hasil estimasi dengan nilai $\mathrm{R}^{2}$ sebesar 0.8929 , serta Standar Erorr (SE) sebesar 0.442. Hasil uji ketelitian model tersebut menunjukkan bahwa model estimasi produksi padi yang diperoleh dalam penelitian ini cocok untuk diaplikasikan dengan tingkat akurasi pendugaan mencapai $89.29 \%$, serta standar error pendugaan sebanyak \pm 0.442 ton/ha.

\section{SIMPULAN DAN SARAN}

\subsection{Simpulan}

Estimasi hasil produksi padi dapat dilakukan dengan menggunakan citra Satelit Landsat 8, pada kondisi normal nilai NDVI berkorelasi positif terhadap hasil produksi padi. Pendugaan hasil produksi padi dengan citra Landsat 8 dapat dilakukan pada saat tanaman padi berumur 67 sampai 77 hari setelah tanam, atau sekitar umur 2 bulan. Model estimasi produksi padi yang diperoleh adalah $\mathrm{y}=$ $2.0442 \mathrm{e}^{1.8787 x}$ (dimana $\mathrm{x}$ adalah nilai NDVI citra Landsat 8 dan y merupakan hasil produksi padi). Rata-rata hasil produksi padi di Kabupaten Klungkung berdasarkan analisis citra satelit Landsat 8 adalah 7.24 ton/ha.

Berdasarkan hasil uji ketelitian yang dilakukan terhadap model estimasi produksi padi, dapat disimpulkan bahwa model yang diperoleh cocok digunakan untuk menduga hasil produksi padi bersadarkan pada hasil uji t yang menyatakan antara data statistik dan data estimasi dengan tidak berbeda nyata (non signifikan) pada taraf á $=0.73$. Tingkat akurasi pendugaan model estimasi produksi padi yang diperoleh adalah sebesar $89.29 \%$ dengan standar error pendugaan produksi sebesar \pm 0.443 ton/ha.

\subsection{Saran}

Penggunaan citra satelit Landsat 8 untuk menduga produksi padi harus memperhatikan umur tanaman padi di lapangan dan menggunakan citra satelit yang terbebas dari awan untuk menghindari gangguan yang mempengaruhi akurasi model estimasi produksi padi.

\section{DAFTAR PUSTAKA}

Ali, S. M. dan S. S. Salman. 2015. Estimating the Yield of Rice Farms in Southern Iraq using Landsat Image. International Journal of Scientific \& Engineering Research. 8(6):1607--1614.

Genc, L., M. Inalpulat, U. Kizil, dan S. Aksu. 2014. Determination of Paddy Rice Field Using Landsat 8 Image. International Conference on Biological, Civil and Enviromental Engineering (BCEE). Dubai March: 17-18.

Kania, D. S., I. H. Ismullah, W. N. Sulasdi, dan A. B. Harto. 2010. Estimasi Produktivitas Padi Sawah Berbasis Kalender Tanam Heterogen Menggunakan Teknologi Penginderaan Jauh. J.Rekayasa. XIV(3):110-124.

Lillesand, T. M. dan R. W. Kiefer. 1990. Penginderaan Jauh dan Interpretasi Citra. Dulbahri, P. Suharsono, Hartono, Suharyadi, penerjemah; Sutanto (editor). Yogyakarta: Gadjah Mada University Press. Terjemahan dari: Remote Sensing and Image Interptetation.

Murtiningrum, W., A. Purba, S. D. Lubis, dan W. Wardana. 2011. Model Matematika Pertumbuhan Jumlah Anakan dan Tinggi Tanaman Padi Yang Ditanam dengan Metode SRI. J. Agrotek. 5(2): 92-107

Nuarsa, I W. dan F. Nishio. 2007. Relationships Between Rice Growth Parameters and Remote Sensing Data. International Journal of Remote Sensing and Earth Sciences, 4:102-112.

Nuarsa, I W., F. Nishio, dan C. Hongo. 2011Spectral Characteristics and Mapping of Rice Plants Using Multi-Temporal Landsat Data. Journal of Agricultural Scienc. 3(1):54-67.

Nuarsa, I W., F. Nishio, dan C. Hongo. 2012. Rice Yield Estimation Using Landsat ETM+ Data and Field Observation. Journal of Agricultural Scienc. 4(3):45-56.

Panuju, D. R., F. Heidina, B. H. Trisasongko, B. Tjahjono, A. Kasno, A. H.A. Syafril. 2009. Variasi Nilai Indeks Vegetasi MODIS pada Siklus Pertumbuhan Padi. J. Geomatika. 15(2):9-16.

Purwanto, A.. 2015. Pemanfaatan Citra Landsat 8 untuk Identifikasi Normalized Difference Vegetation Index (NDVI) di Kecamatan Silat Hilir Kabupaten Kapuas Hulu. J. Edukasi. 13(1):27-36. 
Said, H. I., S. Subiyanto, dan B. D. Yuwono. 2015. Analisis Produksi Padi dengan Penginderaan Jauh dan Sistem Informasi Geografis di Kota Pekalongan. J. Geodesi Undip. 4(1):1-8.

Sari, V. D. dan B. M. Sukojo. 2015. Analisa Estimasi Produksi Padi Berdasarkan Fase Tumbuh dan Model Peramalan Autoregressive Intgrated Moving Average (ARIMA) menggunakan Citra Satelit Landsat 8 (Studi kasus: Kabupaten Bojonegoro). J. GeoId. 10(2):194-203.

Sitanggang, G. 2010. Kajian Pemanfaatan Satelit Masa Depan: Sistem Penginderaan Jauh Satelit LDCM (Landsat-8). Pusat Pemanfaatan Penginderaan Jauh. [diakses tanggal: $12 \mathrm{Mei}$ 2017]. Availabel from: URL: http:// jurnal.lapan.go.id/.
Siyal, A. A., J. Dempewolf, dan I. B. Reshef. 2015. Rice yield estimation using Landsat ETM+ data. Journal of Applied Remote Sensing. 9:1-16.

Subrata dan R. Kusmana. 2003. Koreksi Terhadap Cara Pengukuran Ubinan Tanaman Padi. Buletin Teknik Pertanian. 8(1):15-18.

Sudarsono, N. W., B. Sudarsono, dan A. P. Wijaya. 2016. Analisis Fase Tumbuh Padi Menggunakan Algoritma NDVI, EVI, SAVI, dan LSWI pada Citra Landsat 8. J. Geodesi. 5(1):125-134.

Wahyunto, B. Widagdo, dan B. Heryanto. 2006. Pendugaan Produktivitas Tanaman Padi Sawah Melalui Analisis Citra Satelit. J. Informatika Pertanian. 15(1):853-869. 